\title{
Risk Management and Value Creation: Empirical Findings from Government Linked Companies in Malaysia
}

\author{
Jamaliah Said $^{1}$, Md. Mahmudul Alam², Nik Herda Nik Abdullah ${ }^{3} \&$ Nur Nadiah Zulkarnain ${ }^{1}$ \\ ${ }^{1}$ Accounting Research Institute, Universiti Teknologi MARA, Shah Alam, Selangor, Malaysia \\ ${ }^{2}$ School of Economics, Finance \& Banking, College of Business, Universiti Utara Malaysia, Sintok, Kedah, \\ Malaysia \\ ${ }^{3}$ Faculty of Accountancy, Universiti Teknologi MARA, Shah Alam, Selangor, Malaysia \\ Correspondence: Md. Mahmudul Alam, School of Economics, Finance \& Banking, College of Business, \\ Universiti Utara Malaysia, Sintok, Kedah, Malaysia. Tel: 60-1-8246-7050. E-mail: rony000@gmail.com
}

Received: February 2, 2016

Accepted: March 2, 2016

Online Published: March 29, 2016

doi:10.5539/res.v8n2p124

URL: http://dx.doi.org/10.5539/res.v8n2p124

\begin{abstract}
This study is an attempt to assess the status of current level of value creation among the Government Linked Companies (GLCs) in Malaysia. This study collected primary data based on a set of questionnaire survey among 134 executives and managers of GLCs in Malaysia. The data were collected based on opinions of the ten factors of value creation practices by using the five-point Likert scale. The data were analysed using descriptive statistics. Further, the reliability of the data was tested using Cronbach's alpha test, the validity of the data was tested by checking the normality test through skewness and kurtosis, and the consistency of the data was tested using factor analysis. On an average, $80.6 \%$ of the respondents agreed that they focus on these factors of value creation. Overall, the federal owned GLCs place more emphasis on certain elements of value creation than the state owned GLCs. Among the elements of value creation, the state owned GLCs emphasize the most on quality development and brand value creation, where the federal owned GLCs emphasized the most on reputation. The GLCs engaged in service sector emphasized the most on brand value and the GLCs engaged in manufacturing sector emphasized the most on customer satisfaction and quality development. This study suggest that GLCs in Malaysia improve the overall value creation by emphasizing on responsiveness, average return on investment, sales growth, profit growth and average return on sales.
\end{abstract}

Keywords: value creation, Government Linked Companies (GLC), risk, sustainable competitive advantage, Malaysia

\section{Introduction}

The Resource-Based View theory (RBV) focuses on transforming valuable resources of the organization to assist in achieving its goals (Barney, 1991). RBV states that organizations that are able to use or fully utilize their resources, such as raw materials, skills, etc., will have the opportunity to gain competitive advantages over their competitors (Grant, 1991), and offer sustainable competitive advantage to the organization (Macfarlane, 2014). Competitive advantage is a situation where the organization is able to create or improve its product and make it superior to the competitors' product. Sustainable competitive advantage will help the organization cope with the changes in the environment and stay successful in the future (Ketchen \& Short, 2014) by achieving long-term competitive advantage which will be costly and difficult to imitate by their competitors (Papulova \& Papulova, 2006).

Sustainable competitive advantage can bring many advantages, as it is a powerful source for the organization to achieve superior performance and create value for the organization (Gupta \& Benson, 2011). According to Barney (1991), organizations could create competitive advantages by obtaining valuable, rare, inimitable resources and capabilities. Obtaining such resources will lead to value creation and sustainability in the organization. Kraaijenbrink and Spender (2011) also stated that without value creation, the organization would have no added value and thus, there would be no reason for the organization to exist in the market. The success of value creation usually can be differentiated by raising share prices, sales growth, reputation and profitability (Abdullah \& Said, 2015b). Value creation can improve the performance of the organization by maximizing 
earnings per share, ensure high levels of operational effectiveness and remain competitive (Gholami, 2011). This will indirectly help the organization to implement strategies to improve its effectiveness or efficiency and eventually leads to a competitive advantage when it matches the firm's environment (Porter, 1997; Abdullah \& Said, 2015c).

However, there is no guarantee that all of the resources will lead to competitive advantage or value creation. This is because, according to Kraaijenbrink and Spender (2011), people may perceive values differently. What one perceives as valuable may not be the same for another person. Moreover, due to globalization and the increase in competition, it is hard for organizations to sustain and cope with the rapid changes in the environment. Therefore, organizations must be able to offer or create something new in order to differentiate themselves from their competitors. According to Prieto and Revilla (2006), organizations that are able to offer something different in the market have the potential to achieve superior performance and are able to create value for their organization.

Therefore, in order to ensure the sustainability of some government agencies, the government of Malaysia decided to privatize the companies, which led to the formation of the Government-Linked Companies (GLCs). GLCs are defined as companies that achieve the primary commercial objective of the Malaysian government (Khazanah, 2014) and the Malaysian government has a direct controlling stake in these companies (OECD, 2013). The controlling stake refers not only to the percentage of their ownership, but also their direct or indirect influence in the appointment of directors and senior management officers. They also make major decisions such as contracting awards, strategizing, restructuring, financing, and acquisition and divestments through Government-Linked Investment Companies (GLICs). In other words, GLCs are controlled by the Malaysian government via GLICs, Khazanah, Ministry of Finance Inc. (MOF), Employees Provident Fund (EPF) and Bank Negara Malaysia (BNM) (Note 1).

GLCs cover a wide spectrum of economic activities from infrastructure, telecommunication, agriculture to financial services. Thus, GLCs play an important role in the operation of every commercial concern in Malaysia and contribute significantly towards improving the quality of life for the public (Abdullah, 2007; Razak, 2012). GLCs are a corporate entity that may be a private company or a public listed company. However, GLCs only account for about five percent of the total companies in Bursa Malaysia (formerly known as Kuala Lumpur Stock Exchange or KLSE), GLCs' market capitalization amounts to RM 232 billion, which is more than half of Malaysia's Gross Domestic Product (Md Zin \& Sulaiman, 2011).

The main objective of an organization is to improve the performance and the business process of the organization so that they will be as competitive as other companies in the market (Aivazian, Ge, \& Qiu, 2005). According to Phua (2001), the government economic planners believe that the privatization of public services would bring many advantages to the country. This is in line with past evidence that agrees privatization could increase the efficiency of the organization, greater utilization of growth opportunities, reduce the administrative and financial burdens of the Malaysian government, and increase Bumiputera participants in the corporate sector (Nambiar, 2009). However, there are issues in which GLCs are labelled as underperforming, as they deal with dual objectives, which are to make profits and fulfil social obligations. This has given GLCs an adverse image.

Therefore, to overcome the underperformance issue, in May 2004, the government introduced the GLC Transformation Programme. The main objective of this programme is to improve the performance of GLCs and all corporate sectors so that they would perform successfully. This transformation program is important as it is one of the journeys for the organization to achieve Vision 2020. Quite a few GLCs have been successful in implementing the programme, such as Telekom Malaysia, Malaysian Airport Holding Berhad (MAHB), and United Engineering Malaysia (UEM) Group Berhad. These companies have turned out to be more profitable and have been recognized internationally (Md Zin \& Sulaiman, 2011).

However, past studies still show that GLCs is lacking of value creation compared to non-GLCs (Entebang, 2010; Mohamad \& Said, 2011; Lau \& Tong, 2008; Feng et al., 2004; Razak et al., 2011). Muslim et al. (2012) state that GLCs have suffered from recurring poor firm performances due to the lack of value creation in their organization, which has made them come under the government's scrutiny. Razak et al. (2011) find that non-GLCs' performances are better than GLCs in terms of their corporate governance and other forms of specific characteristics, which makes them create more value than GLCs. This is because GLCs do not focus too much on maximizing profits, as they are also concerned about contributing towards nation building (Lau \& Tong, 2008).

Several GLCs are unable to create value and thus suffer from poor performances such as the Malaysian Airline System (MAS) and Proton Holding Berhad. Hence, GLCs need to put in extra initiatives to create value so that 
they will be able to meet the requirements and expectations of the government and at the same time, be able to increase and add value to their products, services and business performance (Lawler \& Mohrman, 2013; Aziz et al., 2015a, 2015b, 2015c; Said et al., 2015). Khazanah (2014) states that GLCs are expected to improve and enhance their value creation by focusing on sustainable practices and execution from 2015 onwards. Value creation of GLCs will improve the firm performance as well as maximize shareholder wealth, which is government, and lead to business excellence (Abdullah \& Said, 2015a). Currently, GLCs, especially G20 (Note 2) companies, have started to focus on sustainable practices to achieve long-term value creation. However, some GLCs tend to undermine the importance of sustainable practices as they have several goals to accomplish. Moreover, there are currently limited researches done on value creation in Malaysian GLCs (Lau \& Tong, 2008). Under this circumstance, this study investigates the practices of value creation among different categories of Government-Linked Companies (GLCs) in Malaysia.

\section{Methodology}

\subsection{Sampling and Data Collection}

The data for this study are collected based on a questionnaire survey among 134 executives and managers of GLCs in Malaysia. The survey was conducted between February and April of 2015.

\subsection{Measurements of Variables}

This study uses ten parameters to measure the value creation adopted from Wang and Wang (2012). Value creation was measured by using two different variables-non-financial aspect and financial aspect. Non-financial aspects are measured based on customer satisfaction, quality development, responsiveness, brand value, environment and community issue, and reputation. The financial aspects are measured through the average return on investment, sales growth, profit growth, and average return on sales. The factors are as follows:

\section{V1 Customer satisfaction \\ V2 Quality development \\ V3 Responsiveness \\ V4 Brand Value \\ V5 Environmental and community issue \\ V6 Average return on investment \\ V7 Sales growth \\ V8 Profit growth \\ V9 Average return on sales \\ V10 Reputation}

The respondents are asked to compare all the value creation measure in their organization against their competitors in the same industry for at least three years. The questionnaire uses a five-point Likert rating scale ranging from 1 (strongly disagree) to 5 (strongly agree).

\subsection{Data Analysis}

The data are analysed using descriptive statistics. Factor analysis is used to measure the consistency of the data. Further, the reliability of the data is tested using the Cronbach's alpha test. Finally, the data validity is tested by checking the normality of data through skewness and kurtosis.

\section{Analysis and Findings}

\subsection{Demographic Information}

The study collected a few demographic data of the respondents, which include gender, age, job position, level of education, number of years working in the GLC, type of industry and the number of employees in the organization. A summary of the demographic information is given in Table 1 . 
Table 1. Demographic information of the respondents

\begin{tabular}{|c|c|c|c|}
\hline Demographic Profile & & Frequency & Percentage (\%) \\
\hline \multicolumn{4}{|l|}{ Gender: } \\
\hline & Male & 55 & 41.0 \\
\hline & Female & 79 & 59.0 \\
\hline \multicolumn{4}{|l|}{ Age Group: } \\
\hline & Under 30 years & 32 & 23.9 \\
\hline & 30 to 40 years & 51 & 38.1 \\
\hline & 41 to 50 years & 33 & 24.6 \\
\hline & 51 years and above & 18 & 13.4 \\
\hline \multicolumn{4}{|l|}{ Level of education: } \\
\hline & SPM/MCE/Certificate & 1 & 0.7 \\
\hline & Diploma & 19 & 14.2 \\
\hline & University degree & 104 & 77.6 \\
\hline & Professional qualification & 10 & 7.5 \\
\hline \multicolumn{4}{|l|}{ Job Position: } \\
\hline & Top management & 7 & 5.2 \\
\hline & Middle management & 68 & 50.7 \\
\hline & Lower management & 59 & 44.0 \\
\hline \multicolumn{4}{|l|}{ Type of industry: } \\
\hline & Service & 53 & 39.6 \\
\hline & Manufacturing & 13 & 9.7 \\
\hline & Others & 68 & 50.7 \\
\hline \multicolumn{4}{|l|}{ Owner Type of GLCs: } \\
\hline & State & 40 & 30 \\
\hline & Federal & 86 & 64 \\
\hline & Other & 8 & 6 \\
\hline \multicolumn{4}{|c|}{ Number of years working in GLCs: } \\
\hline & Less than 1 year & 12 & 9.0 \\
\hline & 1 to 3 years & 26 & 19.4 \\
\hline & 4 to 5 years & 16 & 11.9 \\
\hline & More than 5 years & 80 & 59.7 \\
\hline \multicolumn{4}{|l|}{ No. of employees: } \\
\hline & Less than 100 & 17 & 12.7 \\
\hline & 100 to 500 & 26 & 19.4 \\
\hline & 501 to 1000 & 9 & 6.7 \\
\hline & More than 1000 & 82 & 61.2 \\
\hline
\end{tabular}

Among the respondents, 59\% are female and $41 \%$ are male. Most of the respondents are in the $30-40$ years age group, which comprises $38 \%$ of the total respondents. Majority of the respondents, $77.6 \%$, have a minimum first degree.

Among the respondents, $50.7 \%$ are in the middle management position. In terms of the type of industries, $39.6 \%$ of the respondents are involved in the service sector followed by $9 \%$ in the manufacturing sector, while most of 
them are in other sectors such as broadcasting. Among the GLCs considered in this study, $64 \%$ are owned by the federal government and $30 \%$ by the state governments.

About half of the respondents (59.7\%) have been working for more than 5 years in GLCs. Based on the number of employees, $61.2 \%$ of the respondents work in large organizations that consist of more than 1000 employees.

\subsection{Descriptive Analysis}

The study measures the practices of value creation in the GLCs using ten variables. Among the respondents, on an average, $80.6 \%$ agree that they exercise these factors of value creation and $1.5 \%$ mention that they do not practise them (Table 2).

Table 2. Score of the factors of value creation among the GLCs in Malaysia

\begin{tabular}{llllllllllll}
\hline Score & V1 & V2 & V3 & V4 & V5 & V6 & V7 & V8 & V9 & V10 & $\begin{array}{l}\text { All } \\
\text { Average }\end{array}$ \\
\hline 1 & 1 & 0 & 0 & 0 & 1 & 0 & 0 & 0 & 0 & 0 & 0 \\
2 & 5 & 3 & 2 & 4 & 4 & 12 & 11 & 12 & 12 & 2 & 2 \\
3 & 22 & 22 & 31 & 19 & 28 & 31 & 37 & 29 & 38 & 19 & 24 \\
4 & 74 & 69 & 73 & 62 & 61 & 69 & 65 & 69 & 59 & 73 & 85 \\
5 & 32 & 40 & 28 & 49 & 40 & 22 & 21 & 24 & 25 & 40 & 23 \\
\hline Disagree (1-2) & 6 & 3 & 2 & 4 & 5 & 12 & 11 & 12 & 12 & 2 & 2 \\
Agree (4-5) & 106 & 109 & 101 & 111 & 101 & 91 & 86 & 93 & 84 & 113 & 108 \\
Disagree\% (1-2) & 4.5 & 2.2 & 1.5 & 3.0 & 3.7 & 9.0 & 8.2 & 9.0 & 9.0 & 1.5 & 1.5 \\
Agree\% (4-5) & 79.1 & 81.3 & 75.4 & 82.8 & 75.4 & 67.9 & 64.2 & 69.4 & 62.7 & 84.3 & 80.6 \\
Average & 3.98 & 4.09 & 3.95 & 4.16 & 4.01 & 3.75 & 3.72 & 3.78 & 3.72 & 4.13 & 3.96 \\
Maximum & 1 & 2 & 2 & 2 & 1 & 2 & 2 & 2 & 2 & 2 & 2 \\
Minimum & 5 & 5 & 5 & 5 & 5 & 5 & 5 & 5 & 5 & 5 & 5 \\
Std. Dev. & 0.79 & 0.74 & 0.71 & 0.78 & 0.84 & 0.84 & 0.83 & 0.84 & 0.87 & 0.70 & 0.64 \\
Factor Loading & 0.84 & 0.84 & 0.83 & 0.81 & 0.77 & 0.73 & 0.71 & 0.71 & 0.70 & 0.67 & \\
\hline
\end{tabular}

Among all the factors of value creation, the highest mean score is 4.16 for the factor of brand value (V4), and the lowest mean score is 3.72 for the factor of sales growth (V7) and average return on sales (V9) (Table 2). The average mean value is 3.96. There is scope to improve overall value creation by emphasizing the factors that are below the average score such as improve responsiveness (V3), average return on investment (V6), sales growth (V7), profit growth (V8), and average return on sales (V9).

Table 3. Score of the factors of value creation according to the types of GLCs in Malaysia

\begin{tabular}{lllllllllllll}
\hline \multicolumn{1}{l}{ Category } & & V1 & V2 & V3 & V4 & V5 & V6 & V7 & V8 & V9 & V10 & Total \\
\hline GLC & State & 3.85 & 4.03 & 3.80 & 4.08 & 3.73 & 3.58 & 3.35 & 3.53 & 3.48 & 3.90 & 3.73 \\
Type & Federal & 4.02 & 4.13 & 4.02 & 4.23 & 4.17 & 3.84 & 3.86 & 3.88 & 3.83 & 4.24 & 4.02 \\
& Other & 4.13 & 4.00 & 3.88 & 3.88 & 3.63 & 3.75 & 4.00 & 4.00 & 3.88 & 4.00 & 3.91 \\
\multirow{3}{*}{ Industry } & Service & 3.77 & 3.92 & 3.89 & 4.23 & 4.08 & 3.75 & 3.70 & 3.77 & 3.66 & 4.13 & 3.89 \\
Type & Manufacturing & 4.23 & 4.23 & 4.08 & 4.00 & 3.69 & 3.62 & 3.77 & 3.62 & 3.69 & 4.00 & 3.89 \\
& Other & 4.09 & 4.19 & 3.97 & 4.15 & 4.01 & 3.78 & 3.72 & 3.82 & 3.78 & 4.15 & 3.97 \\
\hline
\end{tabular}

Overall, the federal owned GLCs place more emphasis on the factors of value creation than the state owned GLCs (Table 3). Among the factors of value creation, the state owned GLCs place the most emphasis on quality development (V2), and brand value (V4) but place the least emphasis on sales growth (V7). On the other hand, 
the federal owned GLCs place the most emphasis on reputation (V10) and the least emphasis on average return on sales (V9).

The GLCs engaged in the service sector and manufacturing sector have equal focus on the value creation (Table 3 ). However, the GLCs engaged in the service sector place the most emphasis on brand value (V4) and the least emphasis on average return on sales (V9). On the other hand, GLCs engaged in the manufacturing sector place the most emphasis on customer satisfaction (V1) and quality development (V2) and the least emphasis on average return on investment (V6) and profit growth (V8).

\subsection{Diagnostic Test}

\subsubsection{Normality Test}

The normality test is performed to check the distribution of data. According to Pallant (2013), the normality of the data can be described by using the skewness and kurtosis tests, where the data can be considered normally distributed when the kurtosis value is between -3 to 3 and the skewness value is below zero. For the factors of value creation, the skewness value is -0.54 , and the kurtosis value is 0.166 , which are within the acceptable range. Therefore, the data can be considered as normally distributed.

\subsubsection{Reliability Test}

The Cronbach's alpha (Table 4) value on value creation is 0.92 , which indicates the reliability of the questions is excellent (George \& Mallery, 2003). The eigenvalue for the test indicates that the factor used in value creation explains the $58.4 \%$ variance. The Kaiser-Meyer Olkin test indicates a value greater than 0.6 at 0.897 (Chi-Square $=980.98, \mathrm{p}<0.000$ ). Therefore, the sample is adequate to be used in the factorial analysis. Generally, the test supports the variables of value creation in this study.

Table 4. Reliability test for the factors of value creation

\begin{tabular}{ll}
\hline Cronbach's Alpha & 0.92 \\
Eigen \% variance & 58.41 \\
\hline$\%$ of variance & 58.41 \\
Kaiser-Meyer-Olkin Measure of Sampling Adequacy & 0.897 \\
Bartlett's Test of Sphericity Approx. Chi-Square & 980.98 \\
Bartlett's Test of Sphericity Sig. & 0.000 \\
\hline
\end{tabular}

\subsubsection{Consistency Test}

The factor analysis provides the consistency of these variables for value creation measurement. The factor loadings for all the variables are more than 0.6 (Table 2). The ranges of the loading value of the factor is from 0.67 (V10) to 0.84 (V1 \& V2). This indicates that all of the ten variables are good to measure the practices of value creation in the GLCs of Malaysia.

\section{Conclusions and Recommendations}

Malaysia has targeted to achieve Vision 2020 to become a developed nation, but there are many more steps to be taken in improving value creation in GLCs. This study measured the status of the current practices of value creation among different categories of GLCs in Malaysia by assessing ten related factors. The factor analysis provided the consistency of these ten variables for value creation measurement. $80.6 \%$ of the respondents admitted to exercising these ten factors of value creation, and their average score was 3.96 out of 5 scales.

Therefore, to achieve the sustainable competitive advantage by GLC in Malaysia, there is scope for improving the practices of value creation. Overall, GLCs should emphasize on improving their responsiveness, return on investment, sales growth, profit growth, and return on sales. However, the state owned GLCs as well as GLCs engaged in the manufacturing sector should emphasize on environmental and community issues, while GLCs engaged in the service sector need to focus on customer satisfaction. 


\section{Acknowledgement}

We would like to express our sincere gratitude to the Accounting Research Institute (ARI) and Faculty of Accountancy of Universiti Teknologi MARA, Shah Alam, and the School of Economics, Finance \& Banking, College of Business, Universiti Utara Malaysia, Sintok, Kedah in collaboration with the Ministry of Education Malaysia (MOE) in providing financial assistance to carry out this research project. The research was supported under the Fundamental Research Grant Scheme (FRGS).

\section{References}

Abdullah, N. H. N., \& Said, J. (2015a). Enhancing the Governance of Government Linked Companies via Strategic Management Accounting Practices and Value Creation. Procedia Economics and Finance, 28, 222-229.

Abdullah, N. H. N., \& Said, J. (2015b). The influence of strategy formation capability on firm's value creation: An empirical review. In International Conference on Accounting Studies (ICAS) (pp. 17-20). Johor, Malaysia.

Abdullah, N. H. N., \& Said, J. (2015c). Developing measurement of value creation in Malaysian Government Linked Companies using the Delphi technique. Global Journal of Business and Social Science Review, 3(1), 286-294. Retrieved from http://www.gjbssr.org/pdf_files/Vol-3-PDF.pdf\#page=294

Abdullah, R. (2007). Productivity Performance of Malaysian Government Linked Companies (GLCs) in Plantation Sector. Retrieved from http://ilmuonline.mpc.gov.my/elmu-cis/document/productivity/Productivity1.pdf

Aivazian, V. A., Ge, Y., \& Qiu, J. (2005). Can corporatization improve the performance of state-owned enterprises even without privatization? Journal of Corporate Finance, 11(5), 791-808. http://dx.doi.org/10.1016/j.jcorpfin.2004.11.001

Aziz, M. A. A., Rahman, H. A., Alam, M. M., \& Said, J. (2015b). Enhancement of the Accountability of Public Sectors through Integrity System, Internal Control System and Leadership Practices: A Review Study. Procedia Economics and Finance, 28, 163-169. http://dx.doi.org/10.1016/S2212-5671 (15)01096-5

Aziz, M. A. A., Said, J., \& Alam, M. M. (2015a). An Assessment of the Practices of Leadership Quality in the Public Sectors of Malaysia. Procedia Economics and Finance, 31, 909-918. http://dx.doi.org/10.1016/S2212-5671 (15)01191-0

Aziz, M. A. A., Said, J., \& Alam, M. M. (2015c). Assessment of the Practices of Internal Control System in the Public Sectors of Malaysia. Asia-Pacific Management Accounting Journal, 10(1), 43-62. http://dx.doi.org/10.1016/S2212-5671(15)01191-0

Barney, J. B. (1991). Firm Resources and Sustained Competitive Advantage. Journal of Management, 17, 99-120. http://dx.doi.org/10.1177/014920639101700108

Entebang, H. (2010). Entrepreneurial Orientation and Corporate Entrepreneurship Performance of Government-Linked Companies in Malaysia. Queen's University Belfast, Belfast.

Feng, F., Sun, Q., \& Tong, W. H. S. (2004). Do government-linked companies underperform? Journal of Banking \& Finance, 28(10), 2461-2492. http://dx.doi.org/10.1016/j.jbankfin.2003.10.012

George, D., \& Mallery, P. (2003). SPSS for Windows step by step: A simple guide and reference. Retreived from http://wps.ablongman.com/wps/media/objects/385/394732/george4answers.pdf

Gholami, S. (2011). Value Creation Model through Corporate Social Responsibility (CSR). International Journal of Business and Management, 6(9), 148-154. http://dx.doi.org/10.5539/ijbm.v6n9p148

Grant, R. M. (1991). The Resource-Based Theory of Competitive Advantage: Implication for Strategy Formulation. California Management Review, 33(3), 114-135. http://dx.doi.org/10.2307/41166664

Gupta, N. J., \& Benson, C. C. (2011). Sustainability and Competitive Advantage: An Empirical Study of Value Creation. Competition Forum, 9(1), 121-136. Retrieved from http://ssrn.com/abstract=2037493

Ketchen, D., \& Short, S. (2014). Resource-Based Theory. Mastering Strategic Management. Retrieved from $\mathrm{http} / / /$ catalog.flatworldknowledge.com/bookhub/reader/3085? e=ketchen_1.0-ch04_s01

Khazanah. (2014). GLCs Delivering High Performance and Catalysing Inclusive Growth. Retrieved from http://www.khazanah.com.my/docs/140610\%20GLC\%20Progress\%20Review.pdf

Kraaijenbrink, J., \& Spender, J. C. (2011). Theories of the Firm and their Value Creation Assumptions. In Annual 
International Conference of the Strategic Management Society (pp. 6-9). Miami, US.

Lau, Y. W., \& Tong, C. Q. (2008). Are Malaysian Government Linked Companies (GLCs) creating value? International Applied Economics and Management Letters, 1(1), 9-12. Retrieved from http://econ.upm.edu.my/iaeml/vol1no1/bab02.pdf

Lawler, E. E., \& Mohrman, A. S. (2013). Sustainability: What Should Boards Do? Centre for Effective Organization. University of Southern California.

Macfarlane, M. A. (2014). Sustainable Competitive Advantage for Accountable Care Organizations. Journal of Healthcare Management, 59(4), 263-271. Retrieved from http://search.proquest.com.ezaccess.library.uitm.edu.my/docview/1550823813?accountid=42518

Md Zin, N., \& Sulaiman, S. (2011). Government-linked Companies Blue Book (GLCs Blue Book) as a complement to Balanced Scorecard (BSC) in the Government-Linked Companies transformation program. IACSIT Press, Kuala Lumpur.

Mohamad, N. H., \& Said, F. (2011). Efficiency and innovation in selected Malaysian government-linked companies for the period 2003 to 2008. African Journal of Business Management, 5(25), 10259-10270. http://dx.doi.org/10.5897/ajbm11.579

Muslim, H. S. M., Hafiz, M. A. R., \& Fekri Ali, M. S. (2012). Corporate governance and earnings management in Malaysian government linked companies. Asian Review of Accounting, 20(3), 241-258. http://dx.doi.org/10.1108/13217341211263283

Nambiar, S. (2009). Revisiting Privitisation in Malaysia: The Importance of Institutional Process. Asian Academy of Management Journal, 14(2), 21-40. Retrieved from http://web.usm.my/aamj/14.2.2009/AAMJ_14.2.2.pdf

OECD. (2013). Education at a Glance 2013: OECD Indicators. OECD Publishing. http://dx.doi.org/10.1787/eag-2013-en

Pallant, J. (2013). A Step by Step Guide to Data Analysis Using SPSS program (5th ed.). Allen \& Unwin, Crows Nest, N.S.W.

Papulova, E., \& Papulova, Z. (2006). Competitive strategy and competitive advantages of small and midsized manufacturing enterprises in Slovakia. Slovakia: International Leadership and Networking Conference.

Phua, K. L. (2001). Corporatization and Privatization of Public Services: Origins and Rise of a Controversial Concept. Akademika, 58, 45-57. Retrieved from http://ejournals.ukm.my/akademika/article/view/2966/1891

Porter, M. E. (1997). Competitive Strategy. Measuring Business Excellence, 1(2), 12-17. http://dx.doi.org/10.1108/eb025476

Prieto, I. M., \& Revilla, E. (2006). Learning capability and business performance: A non-financial and financial assessment. The Learning Organization, 13(2), 166-185. http://dx.doi.org/10.1108/09696470610645494

Razak, J. A. (2012). Government-linked Companies Transformation Programme to Spur Change. Retrieved from http://kperspectives.khazanah.com.my/Get_To_Know_Us-@-Government-linked_Companies_Transformati on_Programme_to_Spur_Change.aspx

Razak, N. H. A., Ahmad, R., \& Joher, H. A. (2011). Does government linked companies (GLCs) perform better than non-GLCs? Evidence from Malaysian listed companies. Journal of Applied Finance \& Banking, 1(1), 213-240. Retrieved from http://hdl.handle.net/10419/49040

Said, J., Alam, M. M., \& Aziz, M. A. (2015). Public Accountability System: Empirical Assessment of Public Sector of Malaysia. Asian Journal of Scientific Research, 8(2), 225-236. http://dx.doi.org/10.3923/ajsr.2015.225.236

Wang, Z., \& Wang, N. (2012). Knowledge sharing, innovation and firm performance. Expert Systems with Applications, 39(10), 8899-8908. http://dx.doi.org/10.1016/j.eswa.2012.02.017 


\section{Notes}

Note 1. Retrieved from http://www.khazanah.com.my

Note 2. G20 is the selection of large GLCs which were controlled by GLICs under the GLCT Programme and is used as a proxy for performance of the GLCs. However, G20 currently consists of only 17GLCs due to mergers, demergers, divestments and other corporate exercises over the years.

\section{Copyrights}

Copyright for this article is retained by the author(s), with first publication rights granted to the journal.

This is an open-access article distributed under the terms and conditions of the Creative Commons Attribution license (http://creativecommons.org/licenses/by/3.0/). 